NAGY, GÁBor DÁNIEL

ngd1@rel.u-szeged.hu

senior lecturer

(University of Szeged, Hungary)

\title{
Social network based approaches in the research on religion in Central-Eastern Europe ${ }^{1}$
}

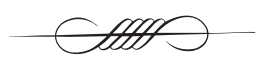

Abstract The network science, based on network theory is a fairly new and innovative field and its approaches are groundbreaking in many aspects. The social scientific applications of the network analysis methods and concepts have been built on the results of network science. Thus, the social network analysis of religious networks is grounded on the methodological principles and assumptions of network analysis, especially social network analysis as it has developed in recent years. In this study the author gives a review of the application of social network theory and social network analysis in the sociology of religion in Central and Eastern Europe. This approach of sociological study of religious faith and religious groups is usually based on empirical research and interpretation of the research results. The sociology of religion has a broader perspective in studying religious life, but the religious social networks usually mirror other characteristics of the studied religious entities and phenomena to make it an interesting subject of research.

Keywords social network analysis, religious social network, religions research, congregational social network, Central and Eastern Europe

DOI 10.14232/belv.2015.1.5 http://dx.doi.org/10.14232/belv.2015.1.5

Cikkre való hivatkozás / How to cite this article:

Nagy, Gábor Dániel: (2015): Social network based approaches in the research on religion in Central-Eastern Europe. Belvedere Meridionale vol. 27. no. 1. 60-70. pp

ISSN 1419-0222 (print)

ISSN 2064-5929 (online, pdf)

1 This research was supported by the European Union and the State of Hungary, co-financed by the European Social Fund in the framework of TÁMOP 4.2.4. A/2-11-1-2012-0001 'National Excellence Program'. 
In this study I plan to review the application of social network theory and social network analysis in the sociology of religion in Central and Eastern Europe. This approach of sociological study of religious faith and religious groups is usually based on empirical research and interpretation of the research results. The sociology of religion has a broader perspective in studying religious life, but the religious social networks usually mirror other characteristics of the studied religious entities and phenomena to make it an interesting subject of research. The network science, based on network theory is a fairly new and innovative field, and its approaches are groundbreaking in many aspects. The social scientific applications of the network analysis methods and concepts have been built on the results of network science. Thus, the social network analysis of religious networks is grounded on the methodological principles and assumptions of network analysis, especially social network analysis as it has developed in recent years. The subjects of research can be the members of religious communities or the communities themselves in this approach.

In the social network analysis method, the selected units of analysis, the cases are represented by nodes, and the connections between them are represented with lines. There can be many forms of connections among different nodes, so there might be different lines used to represent them. The mapping of a religious social network is supposed to be done on an empirical basis, and the results of the mapping shall be interpreted in an objective way. The graphical outcome of social network analysis - in other terms the graph - represents the place of the different actors in the network by points or nodes, and the connections between the different nodes with lines. The interpretation of the graphs is done by the researchers with the help of the graphics and statistical measures. Conclusions can be drawn based on the examination and statistical analyses about the characteristics of the social network. If the researcher wants to go into further detail, there are specific measures developed by network scientists to test their different hypotheses empirically about the network. This new method offers a whole range of new possibilities to do more detailed research on religious networks, but its diffusion among researchers of religion is very slow.

The first instance of using social network analysis in a religious setting can be traced back to the work of Sampson who performed the network analysis of eighteen trainee monks in a monastery (SAMPSON 1969; cited by HERMAN 1984).There were other sociologists applying the traditional sociometric approach to religious groups in the sixties and seventies, for example for clique detection and clustering of individuals. The patterns of the social networks were not examined in the works of this era. (HERMAN 1984).

Another very important boost was given to the SNA method when social scientists realized that the social network parameters of local congregations can be crucial in group development. The social relations developed in the local religious group - congregation settings were vital for the longevity of the group itself. Hoge and Roozen (1979) realized in their research that social factors, such as relationships in a religious group can be well more important in normal cases than the theological disposition. Such result contributed to the widespread diffusion of the social network approach and the SNA method in the American sociology of religion.

I follow the concept of FREEMAN (2004) to identify works that can be categorized based on the usage of SNA methods. He states that the works can be distributed into four categories based on the depth and methodological instances of SNA's application. The four categories are: the scientific work either or fully "(1) involves the intuition where the links among social actors are important. (2) It is based on the collection and analysis of data that record social relations 
that link actors. (3) It draws heavily on graphic imagery to reveal and display the patterning of those links. And (4) it develops mathematical and computational models to describe and explain those patterns" (FREEMAN 2004). The four categories are usually combined in contemporary SNA articles.

I have selected Central and Eastern European articles dealing with religion and social capital which have at least references to social networks. I present my findings based on Freeman's category system.

\section{The social network approach in Central Eastern Europe: the transition era researches}

The historical differences in the development of the societies of the region are very significant compared to the societies of other world regions, but among the countries of the CEE region we can easily identify many parallel processes. Based on the theories of key thinkers such as Paul Zulehner, Miklós Tomka and András Máté-Tóth (MÁTÉ-TóTH - MikluščÁK - Zulehner - Tomka - Toš 200o; Miklos Tomka - Zulehner, 1999; Miklós TomkA - Zulehner 2000), we can state with a high degree of confidence that Central and Eastern Europe has its special regional characteristics in the field of religious faith and belonging, historical and social issues and common value and identity elements determined by the common socialist past.

The most important factor of the CEE region serving as the base of cohesion is the common past that the countries share, and the common experience with the political transition of 1989-1991. The countries used to belong to a block dominated by the Soviet Union which was an absolute power that determined all aspects of social and religious life, and acted like an empire. Its political interests and social value system were forced on all countries in its zone of influence. The Soviet "empire" was not new to the inhabitants of the CEE region, as they had already known historically other empires, such as the Habsburg Empire and the Ottoman Empire which had formerly governed them. The phenomenon of being controlled from a distant political centre with limited degree of autonomy in different matters is a common experience in these countries. The political transition was a major breakthrough in gaining freedom and autonomy in this region which largely contributed to the emergence of nationalism region-wide in all the societies in question (МÁTÉ-TóTH, 2010). The political transition was a major event that seemed to be promising for the entire population of the CEE region, and there were many illusions attributed to it; it was followed by a general expectation of swift social and economic rise in the respective countries. The civil societies of the countries of the region were lacking the real communities "healthy" societies usually have. The "negative modernization" theory of Elemér Hankiss even claimed a general decrease in the communitarian attitudes - a widespread atomization in the societies and infantilisation of the general public.

Most of the communitarian activities were controlled by the state itself before the regime change in these countries. After the significant political event, societies alone had no basis to organize a healthy civil society, whilst the churches already had significant independent social activities in process. For example, in Hungary the Catholic Church had the youth small-groups movement working underground and in addition to the official Church structure, the small neoprotestant churches had the "Council of Free Churches” - ("Szabadegyházak Tanácsa', researched by SZIGETI and RAJKI (2012), and there were many other known religion-related activities of that time. It is fair to say that the transition was preceded and followed by a religious "revival" or by a higher average level of activities of religion-based communities in most societies, which shaped 
the characteristics of the entire event and time period. Social networks based on religious commitment and belonging had a huge role in overcoming the communist past, firstly by actively helping to eradicate the state socialist system, and secondly by helping to build the democratic powers to take over after the regime change. These instances of religious social networking were the first phenomena widely studied by theologians, scholars of religious studies and sociologists of religion. This religious communitarianism decreased to a great extent in the late nineties, and lost its significance of providing a solid basis of social integration and cohesion.

\section{The religious movements of the CEE transition era: Movimenti and others}

The social integration and the new social cohesion were largely determined by religious communitarianism in the era of political transitions in the Central and Eastern European societies. There are many religious movements - most of them acting as social movements themselves - researched in Hungary and in other CEE countries. The general theory of "Movimenti" was elaborated by the example of the Roman Catholic Church in the nineties, but it may refer to the communitarian achievements of the Second Vatican Council as well. The theory had the aim to distinguish between movements and communities, and it refers to lay people living some form of community life. The "Movimenti" members of the different countries started to meet regularly in 1984 on the World Youth Day.

If attempt to review the basic Hungarian bibliography related to Movimenti, we havet to mention the work of István KamaRás (1994) with the title: "Inwardly oriented bases - Bensőséges Bázisok" about the small Catholic communities existing in the era of the political transition. János Dobszay wrote an important book about the history of the Catholic social movement in Hungary "Regnum Marianum" (Dobszay 1991.). András Máté-Tóth compiled a book about another influential social movement of the time called "Bokor - Bush" led by a Catholic monkpriest called György Bulányi (МÁтÉ-Toтн 1996). These works usually contain details about the social structure and networks of these groups, this aspect was inevitably a part of the different analyses, but it was not obviously the most important part.

In a review of the era, Máté-Tóth (2011) writes about forty years of persecution of the underground Catholic movements after the Second World War. According to his opinion, the movements served the renewal and passing on of Christian beliefs, and the members of the small groups were priests, members of different congregations and lay people as well. Máté-Tóth calls these people heroes of faith in his writing, based on their deeds. Obviously, these community leaders had a major role in shaping the groups' norms and values, as well as the important characteristics of the social network in these small religious groups.

\section{The research of small Catholic communities}

István Kamarás writes about small Catholic communities in Hungary after 1945 in his book entitled "Intimate Bases" (1994). These small communities represent simultaneously the unchanged original ideas, the belonging to the Church and the continuous renewal of religious groups. There are major spiritual movements inside the church, and the driving forces of these movements are usually the small communities. Kamarás estimated the number of such communities to 2-3000, their total membership around 30-40 000 and the average groups size to 8 to 15 members. The majority of the members were Catholics. 
Kamarás researched different aspects of these groups: he examined the religious practice in different groups, the different activities inside the groups and the different types of these small groups. He highlighted four different movements: the more than 80 year-old Regnum Marianum movement, which was mainly active in raising preadolescent boys but had its organizational profile broadly extended over the time; the Bokor (Bush) movement established by the Schola Piae monk-priest Györy Bulányi, which proclaimed non-violence, poverty and the strict following of the role model of Jesus; the international movement Fokoláré became popular in Hungary, teaching the importance of living the love of Christ in the everyday life, established by Chiara Lubich; and the Charismatic movement, which have taught the direct involvement of the Holy Spirit in people's everyday lives.

Kamarás examined different network characteristics of small communities, partly belonging to the four introduced major groups. The research questions were about the groups' leadership models, integration and legitimacy of group membership and leadership, the openness and closeness of different groups, and the characteristics of the members of different groups'.

Kamarás's important conclusion about social networks is that small group setting in the Catholic are usually formed around a priest or a charismatic layperson. Kamrás realized that the small groups have different life-cycles, based on group characteristics. He examined in-group dynamics and in-group conflicts, and their effects on the operation of the group. When he wrote about the small groups' out-group connections, he mentioned, that such connections "are low in number even in the early nineties". (KAMARÁs 1994. 108.) The communities rarelyhad connection to the leadership of their own Church; their leaders were usually harassed by the state police and the communist secret agents. Half of the small groups had no connection to any kind of religious organization at all. This is partly caused by intentional self-separation (e.g. Bokor). Kamarás also examined the individual members and their sociological characteristic. In conclusion, we can say that he did a social network analysis without making a sociometrical analysis or drawing a social network map. His research is invaluable to the sociology of religion, as most of the small groups have disappeared, and the facts that Kamarás had recorded can serve as important factors in understanding the religiosity of the transition era Hungary. The research is significant in the social network researches of religion topic as well. Kamarás applied the concepts and some methods of social network analysis because of the nature of his research topic.

\section{The research of Regnum Marianum}

The Regnum Marianum is a Catholic spiritual movement of Hungarian origins. It was established by Hungarian priests on the verge of currents of Catholic spiritual movements worldwide. Its organization dates back to 1896, but it was legally established in 1903. It was founded by nine Catholic priests working independently in parishes. Its original idea was to organize a worldly priest community without the members taking oaths. Its original goal was to help young boys who spent their leisure time on the streets without meaningful activities (DoBszay 1991). The organization was forcefully disbanded under state socialism in 1951, and its leaders were imprisoned. The movement became an underground movement, and struggled heavily against communist oppression by performing and maintaining its activities, establishing small groups and spreading its spirituality. The network approach is seldom present in the work of Dobszay, as his review is mostly historical, but we can conclude that a strong social network of Regnum Marianum groups were active in the 70 s, 80 s and early 90 s. These groups were forced into hid- 
ing and secretive operation, but served as a religious social network for the maintenance of the movement's ideas.

\section{The Bokor movement}

The "Bokor" movement operated in a special way: it was organized the way how Jesus organized his network in Biblical times (Mate-Toth, 1996; Zsumbera, 1998). The organization operated with intense and effective relationships among members who were organized into small groups with approximately 12-15 active members. These small communities were organized into a large religiously based social network, with solid personal ties giving the cement of trust this social movement had - and which enabled it to resist the efforts of the communist secret police to invade the groups. The main idea was about network growth: it was envisaged that the members joining the "Bokor" would develop spiritually in the communities, and would eventually reach adulthood, and establish new small groups with their leadership. In this manner, the social network was supposed to grow like a bush - which did not happen because of the lack of personal skills and motivation. The communities were held together by organizers who were responsible for organizing the meetings and to oversee them. The communities were organized into branches, and branch leaders were elected to enhance horizontal communication inside the community. The communities and the branches were independent, and had regular meetings with different topics. The members were men and women coming from different backgrounds, coming together every two-three weeks and in the summer in a larger event to talk about important questions of faith, life and society. The "Bokor" movement is an excellent example of social networking applied, and its scientific analyses are the first to apply this network approach to the analysis of religious communities in $\mathrm{CEE}$.

The leader of Bokor had a lot of influence on the organization, and Máté-Tóth (MÁTÉТо́тн 2011.) introduces his concept of everyday life heroes through the life and work of Father György Bulányi, the leader of the Bokor Movement. According to him, these heroes, including Bulányi were symbolic figures in the religious field and society as well. Máté-Tóth divided the communist era into two phases, the first between 1945 and 1974, and the second between 1975 and 1990. In this paper, I mainly focus on the second phase called analogically the "Babylonian Captivity" by Máté-Tóth. This second phase was a much less violent era than the first, with less obstacles to religious organizations, but the harassments of the state police and secret agents did not stopped (MÁTÉ-Tóth 2011).

\section{Religious social networks in Hungary before the political transition}

We can conclude, based on the works of Kamarás, Dobszay and Máté-Tóth that the social network analysis concept was widely used in the research of Movimenti groups in pre-transitional Hungary. These groups could not operate freely inside the Hungarian society; they were closely monitored by the police and the secret service. There were obvious violent attempts to regulate or even restrict the operations of these groups. This outside pressure forced these groups to organize themselves in a special and protective way to prevent the infiltration of secret agents and other possible invaders. 


\section{Post-transition era examples of social network approach in the CEE sociology of religion}

Gabriella Pusztai applied the social capital and social network aspects in her work about denominational schools in Hungary (2004). She applied and tested the concepts of Pierre Bourdieu and James Samuel Coleman about cultural capital and the strength of religious social networks with a survey research among high school students attending denominational schools in Hungary. She notes that denominational schools in Hungary are founded on the grounds of tight social networks of believer parents. The schools have also very strong and connected social networks in the grades which makes the students perform better compared to other schools in the academic field. This advantage is not present in public schools or non-religious private schools, because they lack the strong social network surrounding them. The students of denominational schools who come from families with religious background perform better that the children who come from a non-religious background, according to the findings of the research. The concept of Coleman about the better performance of students coming from closed social networks governed by norms was justified in Hungary (Pusztai 2004).

Bahovec, Potocnik and Zrinscak (2007) wrote about social capital and religion. Their article is one of the first reviews in Central Eastern Europe about the problem. They put the theory of social capital in the centre of their research, and did secondary analysis of available EVS survey data to look at the situation in different European countries. They speak about social networks, but they do not apply any direct form of network analysis.

In their research about New Religious Movements in Hungary, MÁTÉ-TótH, TöRöK and NAGY (2008) applied the concepts of social embeddedness in the surveyed religious groups, and the social network concept to see the operation of different NRM networks. They discovered that higher level of social embeddedness and inwardly oriented social network were in strong connection with the high level of religiosity and religious attendance in the case of the Jehovah's Witnesses. The Witnesses had a very strong inwardly oriented social network, most of the individuals' friends were coming fromthe group, there were only some work colleagues in the social network. Weaker social ties linked members to colleagues who were not Witnesses. Marriage connections were formed almost exclusively among the members. The inwardly oriented, closed social network was based on an exclusivist view on salvation as the utmost religious good, and was paired with a perception of hostility of the general society towards the members of the group (MÁTÉ-TótH et al. 2008).

The same research investigated Hungarian Scientologists as well. The findings suggest a more heterogeneous social network compared to the Jehovah's Witnesses. The Scientologists had strong connections outside the religious group, and marriages were not exclusively formed inside the group. The Scientologists tried to establish good connections with the outside World, but still perceived the society's disapproval of their group. (MÁTÉ-TóTH et al. 2008)

The research among Scientologist was extended and continued by MÁTÉ-TóTH and NAGY (2011). A survey research was performed among more than 400 Hungarian Scientologists with a questionnaire putting a special emphasis on social network and social capital aspects. The findings suggested strong in-group solidarity, governed by a special set of network norms, built on a strong social network of religious group members. The social network acted as a safety net for Scientologists, it also provided business and employment opportunities for group members. The social network of the religious group was diverse and homogeneous, and it seemed to be able to help the individual members, as a high percentage of respondents said that they have received 
help from / given help to other Scientologists. The most important form of support was friendly advice, but there was a high proportion of people lending money to other group members, and group members were using their social network to help other members find a job or contracts by having a say in favour of them (MÁTÉ-TótH - NAGY 2011).

NAGY (2010) published an article about the connections of social capital and religion, and the role of religious social networks in social capital formation. The article presented the main concepts of social capital, and did a review on the Central and Eastern European researches. It can be said that the social capital concept was pretty influential, with obvious application in the religious field, but social networks were not studied directly. The social networks were regarded as only one dimension of religious social capital by most researchers.

Sinziana PREDA (2011) studied the social network and identities of Romanian and Czech Baptists. The case of the Romanian immigrant Baptists in the Czech Republic was explained with the social network concept. Romanian Baptist immigrants moved to the Czech lands, escaping from economic hardships. Their religious social network provided protection for them, while they were able to find a job. They were also able to secure their place in Czech society. Their main social network was created from religious belonging, and the Baptist church had an important part in the integration of immigrants in their new social settings. The social and economic part of the process of immigration was made easier, and the trauma was significantly decreased by the religious social network.

\section{The Central Eastern European Articles}

The article's review results are shown in table 2 . We should realize that a lot of articles in the field of sociology of religion researched and theorized the importance of connections between the different social actors. There was a lot of emphasis put on the network aspect study of different religious groups, but most of the researches did not collect specific data about the links among social actors. If we compare the results of Table 2 (CEE) with Table 1 (North America), we can realize that the applications of social network analysis methods and theories are more frequent and used to a greater extent in the North American setting. The theories about social networks are very important in Central Eastern European researches, but the methods were not widely.

It is especially interesting that no graphical imagery was used in any of the Central Eastern European researches to depict religious social networks. The application of these methods is the next step to be taken in the adaptation of the social network analysis. The demand for more elaborate methods of network analysis seems to be realistic, as a lot of works applied the social network theories.

TABLE 1 Central Eastern European Social Network and Religion Articles Categorized

\begin{tabular}{c|c|c|c|c|} 
Author(s) and year & $\begin{array}{c}\text { Category 1 } \\
\text { (realize that links } \\
\text { between social actors } \\
\text { are important) }\end{array}$ & $\begin{array}{c}\text { Category 2 } \\
\text { (collects data about } \\
\text { links among social } \\
\text { actors) }\end{array}$ & $\begin{array}{c}\text { Category 3 } \\
\text { (uses graphic imagery } \\
\text { to find patterns) }\end{array}$ & $\begin{array}{c}\text { Category 4 } \\
\text { (uses heavy statistics to } \\
\text { analyze patterns) }\end{array}$ \\
\hline \hline DOBSZAY 1991. & $\mathrm{X}$ & $\mathrm{X}$ & & \\
\hline KAMARÁs 1994. & $\mathrm{X}$ & $\mathrm{X}$ & & \\
\hline MÁTÉ-TóTH 1996. & $\mathrm{X}$ & $\mathrm{X}$ & & \\
\hline ZsumBERA 1998. & $\mathrm{X}$ & & & \\
\hline
\end{tabular}




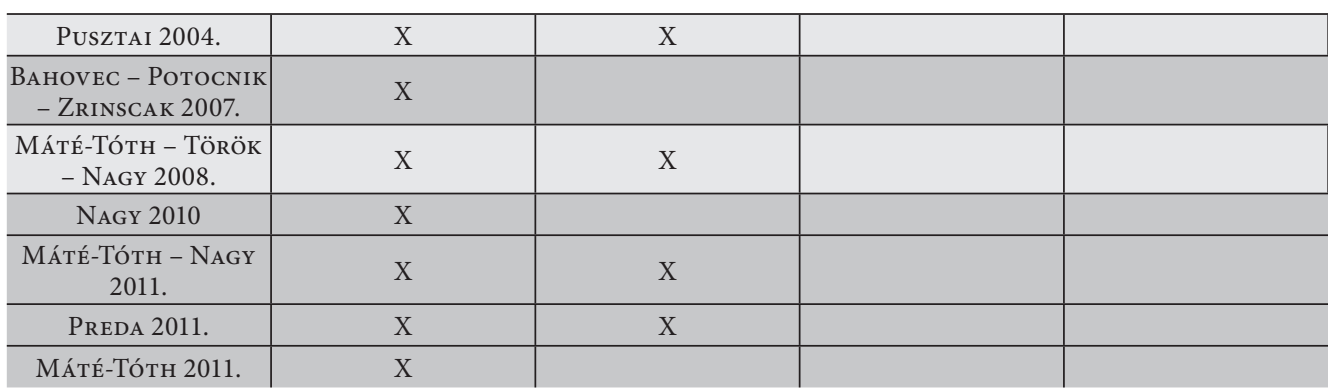

SOURCE Own editing based on FrEEMAN 2004

\section{Conclusions}

This paper analyzed the situation of social network and religion related researches in Central Eastern Europe. The review was conducted on the already published articles. The aim was to find examples of the applications of theory and methods related to social network analysis on behalf of researchers of religion. The articles found were presented in Table 1, and the concept elaborated by FREEMAN (2004) was used to categorize the reviewed works.

The works were selected based on their usage of the social network method, social network theory and the research of different aspects of the religious field. We tried to exclude the topic of social capital and religion, and concentrate on those articles which had a clear social network related topic. We tried to clarify the connections between social capital and social networks to justify the selection of reviewed articles from the overlapping pool. The findings based on the review have shown that the links between social actors are being theorized in the articles, and there are measures introduced to map these links. Most reviewed articles applied empirical methods, and different survey researches concerning different characteristics of the social networks.

There are still many possibilities in the application of the SNA method and theories in the Central Eastern European region setting. The social network mapping of different religious groups could offer a better understanding of many questions asked by the presently reviewed researches. For example, the answer about the specificities of religious networks compared to other social network could be found, if actual SNA researches were performed on the group level. It would be necessary to draw the multi-dimensional social network maps of different communities in a graphical way for further analysis, and for the possibility to use social network statistics. The advantages of the method could be used to answer the research questions which are otherwise hard to overcome, and to pave the ways for new findings and new possible ways of understanding of religious networks.

The possibilities the SNA method are promising for the sociology of religion; it is highly probable that a lot of social network researches will be conducted in religious settings in the coming years to create accurate and meaningful analyses about the operation of the different religious group networks. Connections between different social networks could be also examined, and to get a better understanding of the workings of the contemporary social structure. The possibility of doing such researches is enhanced by new research methods offered by the new technologies, such as smartphones, cheap tablets and extensive social network sites. 


\section{BIBLIOGRAPHY}

Bahovec, I. - Ротocnik, V. - Zrinscak, S. (2007). Religion and Social Capital: the Diversity of European Regions. Social Capital and Governance. Berlin, Lit-Verlag. 175-200.

Brashears, M. E. (2010): Anomia and the Sacred Canopy. Testing a Network Theory. Social Networks vol. 32. no. 3. 187-196. doi: http://dx.doi.org/10.1016/j.socnet.2009.12.003

Coleman, J. A. (2003): Religious Social Capital - Its Nature, Social Location, and Limits. In C. Smidt (Ed.): Religion as Social Capital. Producing the Common Good. Waco (TX), Baylor University Press. 33-47 Davie, G. (2013): The sociology of Religion. A Critical Agenda. Sage.

DobszaY, J. (1991): Igy-vagy Sehogy (This Way or No Way at All). Fejezetek a Regnum Marianum életéből. Budapest.

Durkheim, E. (2012). The Elementary Forms of the Religious Life. Courier Dover Publications.

EIEsland, N. L., - Warner, R. S. (1998). Ecology: Seeing the Congregation in Context. In N. T. A. e. al.] (Ed.), Studying Congregations. Nashville, Abingdon Press. 40-77.

Freeman, L. C. (2004): The Development of Social Network Analysis. Empirical Press Vancouver.

Hamilton, M. B. (2001): The Sociology of Religion: Theoretical and Comparative Perspectives. Psychology Press.

Hankiss, E. (1982): Diagnózisok [Diagnoses]. Budapest, Magvetö.

Herman, N. J. (1984): Conflict in the Church. A Social Network Analysis of an Anglican Congregation. Journal for the Scientific Study of Religion vol. 23. no. 1. 60-74. doi: 10.2307/1385457

Hoge, D. R. - Roozen, D. A. (1979): Understanding Church Growth and Decline, 1950-1978. Pilgrim Press.

Kamarás, I. (1994). 'Bensőséges bázisok. Katolikus kisközösségek Magyarországon'(Intimate Bases. Small Catholic Communities in Hungary). Budapest, Országos Közoktatási Intézet.

Krause, N. - Wulff, K. M. (2005): RESEARCH: "Church-Based Social Ties, A Sense of Belonging in a Congregation, and Physical Health Status". International Journal for the Psychology of Religion vol. 15. no.1. 73-93. doi: 10.1207/s15327582ijpr1501_6

Lewis, V. A. - Macgregor, C. A. - Putnam, R. D. (2013): Religion, Networks, and Neighborliness: The Impact of Religious Social Networks on Civic Engagement. Soc Sci Res vol. 42. no. 2. 331-346. doi: 10.1016/j.ssresearch.2012.09.011

Lim, C. - Putnam, R. D. (2010): Religion, Social Networks, and Life Satisfaction. American Sociological Review vol. 75. no. 6. 914-933. doi: 10.1177/0003122410386686

Mate-Toth, A. (1996): Bulányi und die Bokor-Bewegung. Ungar. Kirchensoziolog. Inst.

Máté-Tóth, A. (2010): Thinking about God in Central and Eastern Europe. In T. Porció (ed.): The Study of Religions in Szeged. Szeged, JATEPress. 55-63

MÁtÉ-Tóth, A. (2011). Heroes of Faith. Paper presented at the Heroes and Celebrities in Central and Eastern Europe. Szeged.

Máté-Tóth, A. - Mikluščák, P. - Zulehner, P. M. - Tomka, M. - Toš, N. (2000): Nicht wie Milch und Honig: unterwegs zu einer Pastoraltheologie Ost (Mittel) Europas.:[eine Veröffentlichung des Oasteralen Forums Wien]. Schwabenverlag.

Máté-Tóth, A. - Nagy, G. D. (2011): Szcientológia Magyarországon. Alternatív Vallásosság (scientology in Hungary. Alternative Religiousness). Budapest, L'Harmattan.

MÁTÉ-Tóth, A. - Töröк, P. - NAGY, G. D. (2008): Az új vallási közösségek viszonya a társadalomhoz / The Relation of New Religious Movement Groups to Society’. In A. Máté-Tóth - G. D. Nagy (eds.): Vallásosság / változatok. Vallási sokféleség Magyarországon. Szeged, JATEPress. 29-46.

McIntosh, W. A. - Sykes, D. - Kubena, K. S. (2002): Religion and Community among the Elderly. The Relationship between the Religious and Secular Characteristics of Their Social Networks. Review of Religious Research vol. 44. no. 2. 109-125. doi: 10.2307/3512511

McPherson, M. - Smith-Lovin, L., - CooK, J. M. (2001): Birds of a Feather: Homophily in Social Networks. Annual Review of Sociology vol. 27. 415-444. doi: 10.2307/2678628

NAGY, G. D. (2010): Faith-based Social Capital in Central and East Europe. In T. Porció (ed.): The Study of Religions in Szeged. Szeged, JATEPress. 65-73. 
PredA, S. (2011): Being Baptist and Being Czech: a Specific Identity in Romania. Journal for the Study of Religions and Ideologies vol. 10. no.30. 56-79.

PuszTaI, G. (2004): Iskola és közösség. Budapest, Gondolat.

Putnam, R. D. - CAmpbell, D. E. (2012): American Grace: How Religion Divides and Unites Us:.Simon and Schuster.

SAMPSON, S. F. (1969): Crisis in the Cloister. Unpublished Ph.D. Dissertation. Cornell University.

Scott, J. - CARrington, P. J. (2011): Introduction. In J. Scott \& P. J. Carrington (Eds.): The SAGE handbook of social network analysis.. London, Thousand Oaks, SAGE publications. 1-8.

StARK, R. - BAINBRIDGE, W. S. (1980): Networks of Faith: Interpersonal Bonds and Recruitment to Cults and Sects. American Journal of Sociology vol. 85. no.6. 1376-1395. doi: 10.2307/2778383

Szigeti, J. - RAJKi, Z. (2012). Szabadegyházak története Magyarországon 1989-ig (The History of Free Churches in Hungary until 1989). Budapest, Gondolat Kiadó.

Tomka, M. - Zulehner, P. M. (1999): Religion in den Reformländern Ost (Mittel) Europas. Schwabenverlag.

Tomka, M. - Zulehner, P. M. (2000): Religion im gesellschaftlichen Kontext Ost (Mittel) Europas. Schwabenverlag AG.

Troeltsch, E. (1992): The Social Teaching of the Christian Churches: Westminster John Knox Press.

Weber, M. (1958): The Protestan Ethic and the spirit of capitalism. Translated by Talcott Parsons. New York, Charlse Scribner.

White, H. C. - Breiger, R. L. (1975): Pattern Across Networks. Society vol. 12. no. 5. 68-74.

Wuthnow, R. (1999): Mobilizing Civic Engagement: The Changing Impact of Religious Involvement. In T. Skocpol - M. P. Fiorina (Eds.): Civic Engagement in American Democracy. Washingtown, D. C., BROOKINGS INSTITUTION PRESS. 331-363.

ZsumberA, Á. (1998): A Bokor kisközösségi mozgalom és a pártállam. "Kváziellenzéki" mozgalom a Kádár-rendszerben (The Bokor Movement of Small Communities and the Single-party State. Quasiopposition in the Kádár System. Valóság vol. 41. no. 8. 52-63. 